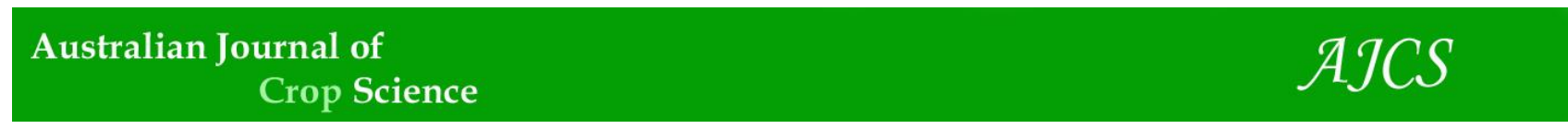

AJCS 14(04):622-626 (2020)

ISSN:1835-2707

\title{
Physiological analysis of papaya seedlings 'Rubi Incaper 511' under different irrigation depths
}

\author{
Vinicius de Souza Oliveira ${ }^{1}$, Stefany Sampaio Silveira ${ }^{2}$, Robson Prucoli Posse ${ }^{2}$, Ana Paula Braido Pinheiro ${ }^{1}$, \\ Karina Tiemi Hassuda ${ }^{1}$, Gleyce Pereira Santos ${ }^{1}$, Jéssica Sayuri Hassuda Santos ${ }^{3}$, Omar Schmildt ${ }^{1}$, Edilson \\ Romais Schmildt ${ }^{3}$
}

\author{
${ }^{1}$ Postgraduate Program in Tropical Agriculture, Federal University of Espírito Santo, São Mateus, ES, Brazil \\ ${ }^{2}$ Federal Institute of Espírito Santo - Campus Itapina, Colatina, Espírito Santo, Brazil \\ ${ }^{3}$ Departament of Agrarian and Biological Sciences, Federal University of Espírito Santo, São Mateus, ES, Brazil
}

\begin{abstract}
One of the main limitations in the process of seedling production is the proper management of irrigation, since this practice implies the costs of orchard implantation. The application of the wrong amount of water leads to water stress in plants causing physiological changes, impairing its development and quality. Thus, the objective of this study was to evaluate the influence of different irrigation slides on the physiological behavior of 'Rubi INCAPER 511' papaya seedlings. The study was conducted during the period from September 9 to November 7, 2016. The experimental design was completely randomized, where the treatments consisted of four different irrigation depth: 8, 10, 12 and $14 \mathrm{~mm} \mathrm{~d}^{-1}$. Each treatment was composed of 24 plants (repetitions), totaling 96 plants in the experiment. 60 days after planting, plant leaves were evaluated using the following physiological characteristics: total chlorophyll content (SFR-G and SFR_R); flavonoid index (FLAV); anthocyanin index (ANT_RG and ANT_RB) and nitrogen balance (NBI_G and NBI_R). Irrigation depth between 10.96 and $11.03 \mathrm{mmd}-1$ provided better values for the analyzed characteristics. Therefore, the $11 \mathrm{mmd}^{-1}$ depth is the most suitable for the production of seedlings, based on the physiological evaluations.
\end{abstract}

Keywords: Carica papaya L., hydrical stress, irrigation management.

\section{Introduction}

The papaya (Carica papaya L.) has great importance in tropical fruit growing, where its cultivation is spread by diverse parts of the world (Souza et al., 2014). India, Brazil, Mexico and Indonesia appear as the main products accounting for about $68 \%$ of world production in 2016 (FAO, 2018). In Brazil, the states of Bahia and Espírito Santo appear as major producers, accounting for $70 \%$ of all national production in 2017 (IBGE, 2018). Among the stages of establishment of a crop, the production of seedlings is of extreme importance because the quality of the seedlings is directly linked to the productive capacity of the adult plants (Costa et al., 2010). The main limitation in this process is the adequate management of irrigation, since this practice implies the costs of orchard implantation (Weckner et al., 2016). Thus, the application of water is done empirically, without specific knowledge, causing the plants not to express their maximum genetic potential and consequently resulting in the decrease of productivity. The availability of erroneous amounts of water to the plants leads the plant to water stress. The lack of water limits the absorption of nutrients by plants, prevents cell expansion, reduces leaf area, increases leaf abscission and reduces the process of photosynthesis (Taiz et al., 2017). Excess water favors the onset of disease, generates leaching of nutrients, and also implies socio-environmental issues due to excessive water consumption (Lopes et al., 2005). This stress can be measured by determining the index of chlorophyll, phenolic compound and secondary compounds, such as flavonoids and anthocyanins by specific devices in a fast and nondestructive way. This technique has been increasingly used in studies involving the behavior of plant species under such conditions (Berilli et al., 2016). Determination of ideal amount of water that to be used in the production of papaya seedlings in a way that does not cause physiological changes in the plants, allows the elaboration of more efficient protocols that reduce the implantation costs of the crops and favor the production of seedlings with better quality (Delgado et al., 2017). Thus, efficient management of natural resources such as water and understanding their behavior under the physiological characteristics of plants is critical to a conscious consumption. The objective of this work was to evaluate the influence of different irrigation depth on the physiological behavior of 'Rubi INCAPER 511' papaya.

\section{Results and discussion}

After analysis of variance and regression analysis by F-test at $5 \%$ probability, there was a statistical difference for flavonoids index (FLAV), total chlorophyll content (SFR_G and SFR_R) and nitrogen balance (NBI_G and NBI_R). No 
significant difference was observed for the anthocyanin index (ANT_RG and ANT_RB).

Note that, in general, there was influence of the availability of water offered to the plants in the characteristics analyzed by the Multiplex meter, noting the negative effect of lack or excess of water on the seedlings. The plants of papaya are extremely sensitive to the amount of water used in their cultivation, and inadequate application created a stressful environment as observed by Oliveira et al. (2019) studying the influence of different irrigation depth on the development and quality of seedlings of papaya. Under these conditions according to Peteinatos et al. (2016) the plants present values of the Multiplex measurements different from plants without stress, which is a good indicator of the physiological state of the plant.

\section{Flavonoid index}

The flavonoid index (FLAV) presented a quadratic adjustment, with the lowest index of -0.076 in the irrigation depth of $11.02 \mathrm{~mm} \mathrm{~d}^{-1}$, with $\mathrm{R}^{2}$ of 0.9883 (Fig. 1). Flavonoids are compounds that favor the survival of plants offering protection against diseases and UV-B radiation due to their presence in the leaves. Besides, they are present in reactions of photosensitization, energy transfer, hormonal balance, regulation of growth and development of plants and control of photosynthesis (Middleton Jr. and Chithan, 1993, Harborne and Baxter, 1999, Harborne and Williams, 2000). Another important function attributed to flavonoids is the protection of cells against stress, reacting with reactive oxygen species that are generated by electron transport in the process of photosynthesis (Harborne, 1994). According to Taiz et al. (2017), reactive oxygen species are the most common toxic compounds produced by plants under stress conditions, being able to rapidly oxidize proteins, DNA, RNA, lipids and organelles leading to cell lysis.

Thus, it is verified that under the smaller and larger irrigation depth there was induction in the flavonoid production, attesting that under these conditions the plants presented a state of stress, since in these cases the plant species tend to increase the production of flavonoids, leading to accumulation in their tissues (Kandil et al., 2004).

\section{Anthocyanin index}

In relation to anthocyanin index (ANT_RG and ANT_RB), it was verified that the treatments did not differ among themselves, with a mean of 0.0063 and -0.5938 (Fig. 2). The role of anthocyanins resembles those of flavonoids related to the defense mechanisms against solar radiation providing the plants with biological functions (Lopes et al., 2007). However, unlike what happened with the flavonoid index, no changes were observed in the anthocyanin index under stress conditions of papaya leaves.

According to Coutinho et al. (2009) anthocyanin is a class of flavonoids. Other compounds such as flavans, flavones, flavonols and isoflavonoids are also found in plant species. Thus, the flavonoid index is not controlled exclusively by the amount of anthocyanins present in plants (Quartezani et al., 2018). This explains the different behaviors between the flavonoid and anthocyanin index present in the 'Rubi INCAPER 511' papaya seedlings.

\section{Total chlorophyll}

The SFR_G and SFR_R indices, representing the total chlorophyll content, showed quadratic behavior, with a maximum point of 1.81 and 1.62 in the irrigation depth of 10.96 and $10.97 \mathrm{~mm} \mathrm{~d}^{-1}$ and $\mathrm{R}^{2}$ of 0.9906 and 0.9887 , respectively (Fig. 3). Chlorophylls are green pigments found in the chloroplast of plant cells that have the function of absorbing light and transfer electrons during the process of photosynthesis. So, without the chlorophyll the carbon fixation is impaired and the energy production in the cells ceases and consequently the growth and development of the plants (Taiz et al., 2017).

\section{Nitrogen balance}

The nitrogen balance (NBI_G and NBI_R) presented quadratic adjustment, with a maximum point of 2.14 and 1.91 in the irrigation depth of 11.03 and $11.02 \mathrm{~mm} \mathrm{~d}^{-1}$, with $\mathrm{R}^{2}$ of 0.9874 and 0.9905 (Fig. 4). These results are similar to those found by Peteinatos et al. (2016) that evaluated the effect of water stress on wheat plants. They found that plants under stress had lower values of nitrogen balance.

Nitrogen is the nutrient most required by plants, so higher values of the nitrogen balance are more desirable, since the deficiency of this nutrient is detrimental to the plants, resulting in a decreased growth and development (Taiz et al., 2017). Thus, their availability may directly interfere with seedling quality.

Note that the behavior of the equations for the nitrogen balance is similar to those found for the total chlorophyll content, with maximum points very close to the irrigation depth of $11 \mathrm{~mm} \mathrm{~d}^{-1}$. This result is expected since nitrogen is a constituent part of the chlorophyll molecule, so it is possible to verify that under this irrigation depth nitrogen was more available to the plants. Another important fact that should be taken into account is that the plants were submitted to the same nutritional conditions. This reinforces that the water regime interfered in the amount of nitrogen present in the plants.

Note, that the nitrogen balance is inversely proportional to the flavonoid index. The results of this study were similar to those reported by Sales et al. (2018), who studied the physiological behavior of Schinus terebinthifolius RADDI leaf grown under different sources of organic matter. They found a decrease in the flavonoid index in relation to the increase in nitrogen content.

According to Freitas (2006), this is dueto the inability of plants to use photoassimilates for the synthesis of amino acids and other nitrogen compounds and demand for the synthesis of phenolic compounds such as flavonoids. Thus, the amount of phenolic compounds synthesized by plants is increased under nitrogen deficient conditions and decreased under high nitrogen availability (Haukioja et al., 1998).

In summary, based on the results obtained in this study, it can be observed that seedlings of 'Rubi INCAPER 511' papaya are sensitive to the amount of water applied to their cultivation, being that the lack or excess interferes negatively in growth and quality seedlings. It was verified that under these conditions there was an increase in the 


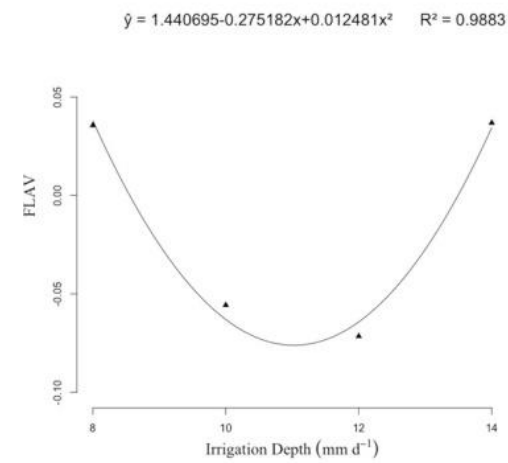

Fig 1. Equation of quadratic model for flavonoid index (FLAV) of 'Rubi INCAPER 511' papaya seedlings under different irrigation depth.
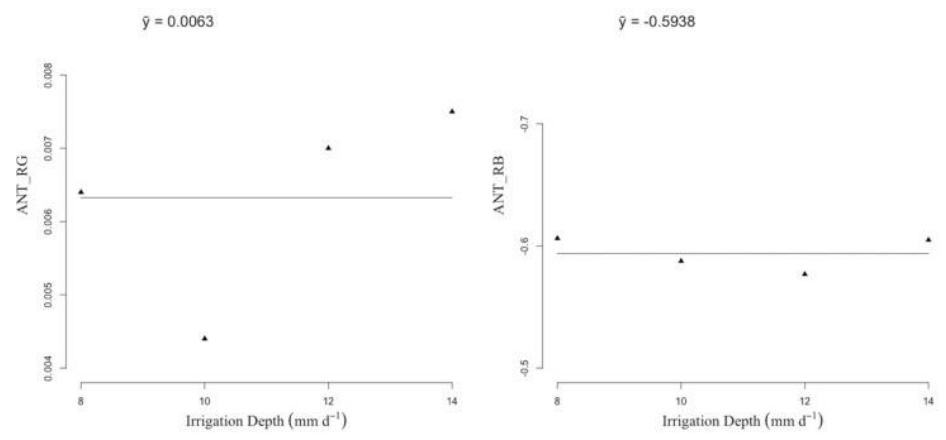

Fig 2. Anthocyanin index (ANT_RG and ANT_RB) of 'Rubi INCAPER 511' papaya seedlings under different irrigation depth.
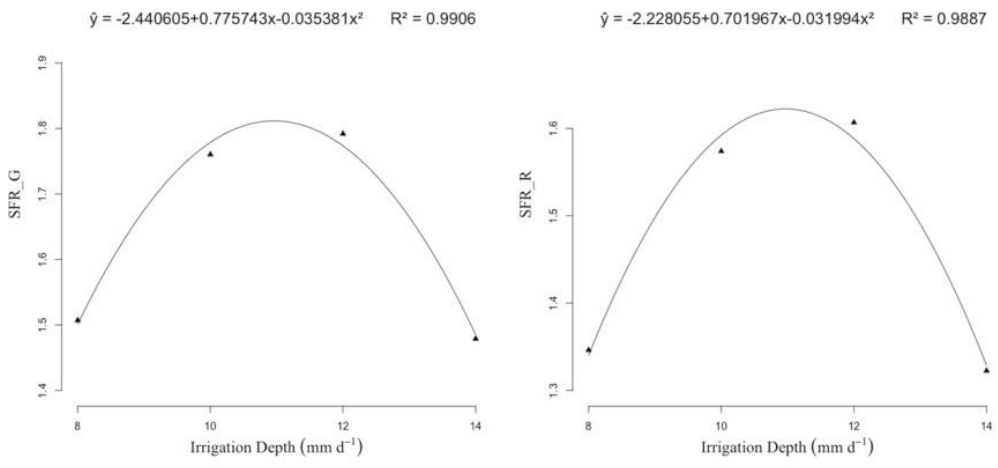

Fig 3. Equation of quadratic model for total chlorophyll content (SFR_G and SFR_R) of 'Rubi INCAPER 511' papaya seedlings under different irrigation depth.
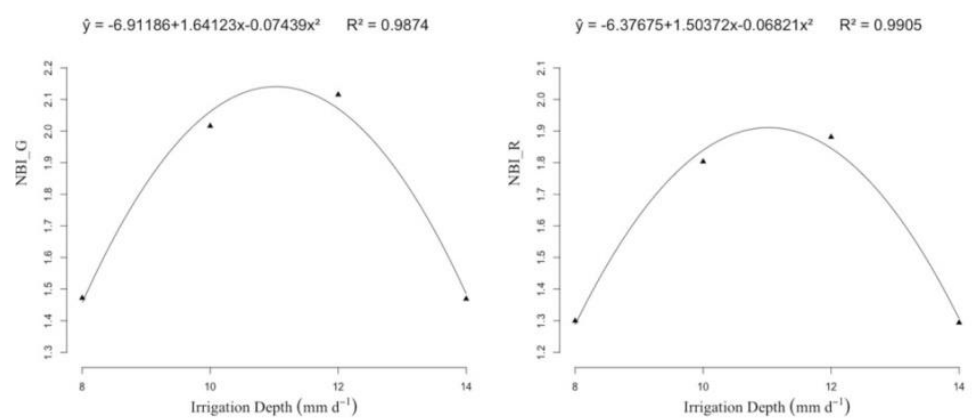

Fig 4. Equation of quadratic model for nitrogen balance (NBI_G and NBI_R) of 'Rubi INCAPER 511' papaya seedlings under different irrigation depth. 


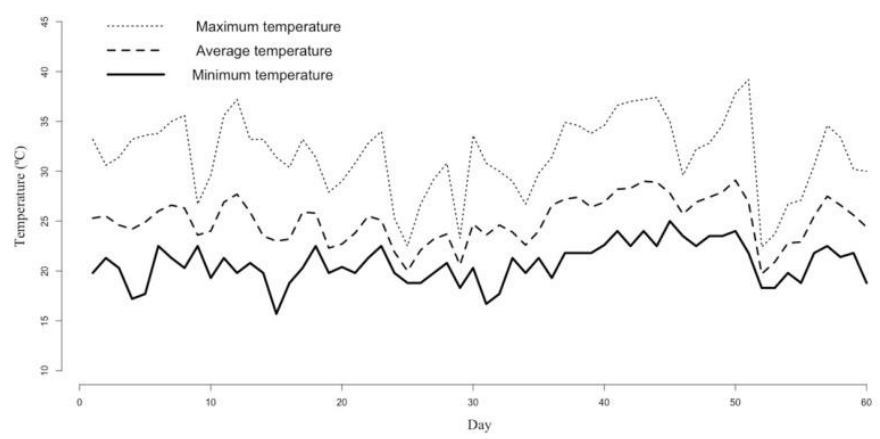

Fig 5. Average, maximum and minimum temperatures during the experiment period in Colatina, Espírito Santo.

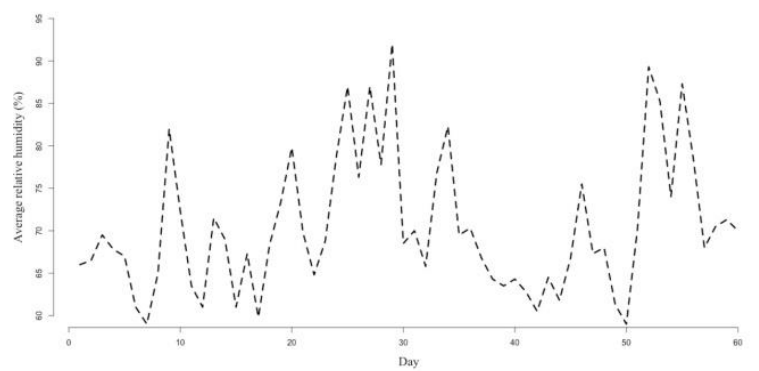

Fig 6. Average relative humidity during the experiment period in Colatina, Espírito Santo.

antioxidant index, such as flavonoids and decrease in the levels of total chlorophyll content and nitrogen balance.

\section{Materials and methods}

\section{Location of the experiment}

The study was conducted at the Federal Institute of Espírito Santo, Campus Itapina, located in the municipality of Colatina, in the Northwest of the State of Espírito Santo, Brazil, located at latitude $19^{\circ} 32^{\prime} 22^{\prime \prime}$ South and $40^{\circ} 37^{\prime} 50^{\prime \prime}$ of longitude West, during the period from September 9 to November 7, 2016. The climate of the region is classified according to Köppen (1936) as Tropical Aw. The mean, maximum and minimum temperatures in the experimental period are shown in Fig. 5 and the mean relative humidity in Fig. 6.

\section{Experimental design}

The study was carried out in greenhouse, sized $25 \mathrm{~m}$ in length and $5 \mathrm{~m}$ in width and $3 \mathrm{~m}$ high covered with clear plastic canvas and black polypropylene canvas with $50 \%$ shading. Inside the greenhouse four individual environments were built, with linear dimensions of $2.20 \mathrm{~m}$ by $1.10 \mathrm{~m}$, covered with transparent plastic canvas on the sides. Each environment consisted of six GREEN MIST (NaanDanJain ) nebulizers spaced $0.8 \mathrm{~m}$ apart and located $1 \mathrm{~m}$ above the seedlings. The irrigation was carried out individually, maintained by centrifugal pumps of $0.5 \mathrm{cv}$, controlled electronically with irrigation shift distributed for 10 hours per day and service pressure of $2 \mathrm{kgf} \mathrm{cm}^{-2}$. The experimental design was completely randomized, where the treatments consisted of four different irrigation depth: 8, 10, 12 and 14 $\mathrm{mm} \mathrm{d}^{-1}$, each treatment was composed of 24 plants, totaling
96 plants (repetitions), in the experiment. The seedlings were produced in tubes with a volume of $280 \mathrm{~cm}^{3}$, presanitized with $2 \%$ solution of sodium hypochlorite and alternately packed in cell trays to prevent shading. Each tube was filled with Tropstrato $\mathrm{HT}^{\circ}$ commercial vegetable substrate plus Osmocote Plus 15-9-12 (3M), at a dosage of $12 \mathrm{~kg} / \mathrm{m}^{3}$, with the following chemical composition: $\mathrm{N}=$ $15 \%$, ( $7 \%$ ammonia and $8 \%$ nitrate), $\mathrm{P}_{2} \mathrm{O}_{5}=9 \%, \mathrm{~K}_{2} \mathrm{O}=12 \%$, $\mathrm{Mg}=1.3 \%, \mathrm{~S}=5.9 \%, \mathrm{Cu}=0.05 \%, \mathrm{Fe}=0.46 \%, \mathrm{Mn}=0.06 \%$ and $\mathrm{Mo}=0.02 \%$. The papaya seeds were of the 'Rubi INCAPER 511' variety. Two seeds were sown per tube. At 15 days after sowing, thinning was carried out with only one seedling per tube. During the period of the experiment, the temperature and relative humidity was measured an ONSET weather station installed outside to the monitoring of climatic variations.

\section{Assessment of characteristics}

At the end of the experiment (60 days after planting) one leaf from each plant was evaluated for the following physiological characteristics: total chlorophyll content (SFR_G and SFR_R); flavonoid index (FLAV); anthocyanin index (ANT_RG and ANT_RB) and nitrogen balance (NBI_G and NBI_R). All analyzes were performed using a Multiplex (Force-A, Orsay, France) model, where the indices represented by the letter $\mathrm{G}$ indicate measurements obtained by the green light and the indices represented by the letter $R$ by the red light.

\section{Statistical analyses}

The data were submitted to analysis of variance and regression analysis by the $\mathrm{F}$ test at $5 \%$ probability. When significant, models of equations were adjusted that best 
explained the behavior of the characteristics analyzed in relation to the applied irrigation depth. The maximum and minimum points were obtained through the primary and secondary derivative of each equation. All the statistical analyzes were done with the help of software $R$ ( $R$ Core Team, 2018).

\section{Conclusions}

The lack or excess of water were detrimental to the seedlings of papaya 'Rubi INCAPER 511'. Irrigation depth between 10.96 and $11.03 \mathrm{~mm} \mathrm{~d}^{-1}$ provided better values of the characteristics analyzed. Thus, for reasons of ease of application, the $11 \mathrm{~mm} \mathrm{~d}^{-1}$ depth is the most suitable for the production of seedlings, based on the physiological evaluations.

\section{References}

Berilli SS, Zooca, AAF, Rembinski J, Salla PHH, Almeida JD, Martineli L (2016) Influência do acúmulo de cromo nos índices de compostos secundários em mudas de café conilo. Coffee Science. 11: $512-520$.

Coutinho MA, Muzitano MF, Costa S (2009) Flavonoides: Potenciais agentes terapêuticos para 0 processo inflamatório. Revista Virtual de Química, 1: 241-256.

Costa E, Leal PAM, Santos LCR, Vieira LCR (2010) Crescimento de mudas de mamoeiro conduzidas em diferentes ambientes protegidos, recipientes e substratos na região de Aquidauana, estado do Mato Grosso do Sul. Acta Scientiarum Agronomy. 32: 463-470.

Delgado LGM, Silva RBG, Silva MR (2017) Qualidade morfológica de mudas de ingá sob diferentes manejos hídricos. Irriga Botucatu. 22: 420-429.

Food and Agriculture Organization of the United Nations FAO. (2018). The agricultural production. http://www.faostat.org

Freitas MSM (2016) Flavonóides e nutrientes minerais em folhas de maracujazeiro amarelo e deficiência de macronutrientes e boro em maracujazeiro doce. 2006, 106 f. Tese (Doutorado em Produção Vegetal) - Universidade Estadual do Norte Fluminense Darcy Ribeiro, Campos dos Goytacazes, Rio de Janeiro, Brazil.

Harborne JB (1994) Flavonoids: Advances in Research Since 1986. Chapman and Hall: London.

Haukioja E, Ossipov V, Koricheva J, Honkanen T, Larsson S, Lempa K (1998) Biosynthetic origin of carbon-based secondary compounds: cause of variable responses of woody plants to fertilization. Chemoecology. 8: 133- 139.

Harborne JB, Baxter H (1999) The handbook of natural flavonoids, (1 and 2). Chichester, UK: John Wiley and Sons.

Harborne JB, Williams CA (2000) Advances in flavonoid research since 1992. Phytochemistry. 55: 481-504.

Instituto Brasileiro de Geografia e Estatística - IBGE (2018) Produção agrícola municipal: Área plantada ou destinada à colheita, área colhida, quantidade produzida, rendimento médio e valor da produção das lavouras temporárias e permanentes. https://sidra.ibge.gov.br/tabela/5457

Kandil FE, Grace MH, Seigler DS, Cheeseman JM (2004). Polyphenolics in Rhizophora mangle L. leaves and their changes during leaf development and senescence. Trees. 18: 518-528.

Köppen W (1936) Das geographische system der klimate. In: Köppen GW, Geiger MR. (eds.), Handbuch der Klimatologie, Berlin: Gebrüder Bornträger.

Lopes JLW, Guerrini IA, Saad JCC (2005) Efeitos de lâminas de irrigação na produção de mudas de Eucalyptus grandis W. (HILL ex. MAIDEN) em substrato de fibra de coco. Irriga, 10: $123-134$.

Lopes T, Xavier M, Quadri MG, Quadri M (2007) Antocianinas: uma breve revisão das características estruturais e da estabilidade. Revista Brasileira Agrociência. 13: 291-297.

Middleton Jr E, Chithan K (1993) The impact of plant flavonoids on mam- malian biology: implications for immunity, inflammation and cancer. The flavonoids: advances in research since 1986. Chapman and Hall: London, UK.

Oliveira VS, Posse RP, Pinheiro APB, Costa GS, Malikouski RG, Morais AL, Schmildt, ER (2019) Effect of irrigation depths on the growth of papaya seedlings. Journal of Experimental Agriculture International, 29: 1-9.

Peteinatos GG, Korsaeth A, Berge TW, Gerhards R (2016) Using optical sensors to identify water deprivation, nitrogen shortage, weed presence and fungal infection in wheat. Agriculture. 6: 24.

Quartezani WZ, Sales RA, Pletsch TA, Berilli SS, Nascimento AL, Hell LR, Mantoanelli, E, Berilli APCG, Silva RTP, Toso R (2018) Conilon plant growth response to sources of organic matter. African Journal of Agricultural Research. 13: 181-188.

R Core Team (2018) R: a language and environment for statistical computing. Vienna: R Foundation for Statistical Computing, Vienna, Austria.

Sales RA, Sales RA, Nascimento TA, Silva TA, Berilli SS, Santos RA (2017) Influência de diferentes fontes de matéria orgânica na propagação da Schinus terebinthifolius RADDI. Revista Scientia Agraria. 18: 99-106.

Souza JMA, Ataíde EM, Silva MS (2014) Qualidade póscolheita e correlação entre características físicas e químicas de frutos de mamoeiro comercializados em Serra Talhada - PE. Magistra, 26: 554-560.

Taiz L, Zeiger E, Moller IM, Murphy A (2017) Fisiologia e desenvolvimento vegetal (6th ed.). Porto Alegre: Artmed.

Weckner FC, Campos MCC, Nascimento EP, Mantovanelli BC, Nascimento MF (2016) Avaliação das mudas de mamoeiro sob o efeito da aplicação de diferentes composições de biofertilizantes. Revista da Universidade Vale do Rio Verde. 14: 700-706. 